\title{
Full latitudinal marine atmospheric measurements of iodine monoxide
}

5 Hisahiro Takashima ${ }^{1,2}$, Yugo Kanaya ${ }^{2}$, Saki Kato ${ }^{1}$, Martina M. Friedrich ${ }^{3}$, Michel Van Roozendael ${ }^{3}$, Fumikazu Taketani ${ }^{2}$, Takuma Miyakawa ${ }^{2}$, Yuichi Komazaki ${ }^{2}$, Carlos A. Cuevas ${ }^{4}$, Alfonso Saiz-Lopez ${ }^{4}$, and Takashi Sekiya ${ }^{2}$

${ }^{1}$ Faculty of Science, Fukuoka University, Fukuoka, Japan

${ }^{2}$ Japan Agency for Marine-Earth Science and Technology (JAMSTEC), Yokohama, Japan

$10 \quad{ }^{3}$ Belgian Institute for Space Aeronomy (BIRA-IASB), Brussels, Belgium

${ }^{4}$ Department of Atmospheric Chemistry and Climate, Institute of Physical Chemistry Rocasolano (CSIC), Madrid, Spain Correspondence to: Hisahiro Takashima (hisahiro@fukuoka-u.ac.jp) and Yugo Kanaya (yugo@jamstec.go.jp)

Abstract. Iodine compounds destroy ozone $\left(\mathrm{O}_{3}\right)$ in the global troposphere and form new aerosols, thereby affecting the global

15 radiative balance. However, few reports have described the latitudinal distribution of atmospheric iodine compounds. This work reports iodine monoxide (IO) measurements over unprecedented sampling areas from Arctic to the Southern Hemisphere and spanning sea surface temperatures (SSTs) of approximately $0^{\circ} \mathrm{C}$ to $31.5^{\circ} \mathrm{C}$. The highest IO concentrations were observed over the Western Pacific warm pool (WPWP), where $\mathrm{O}_{3}$ minima were also measured. There, negative correlation was found between $\mathrm{O}_{3}$ and $\mathrm{IO}$ mixing ratios at extremely low $\mathrm{O}_{3}$ concentrations. This correlation is not explained readily by the " $\mathrm{O}_{3}$ -

20 dependent" oceanic fluxes of photolabile inorganic iodine compounds, the dominant source in recent global-scale chemistrytransport models representing iodine chemistry, and rather implies that " $\mathrm{O}_{3}$-independent" pathways can be similarly important in the WPWP. The $\mathrm{O}_{3}$-independent fluxes result in a $15 \%$ greater $\mathrm{O}_{3}$ loss than that estimated for $\mathrm{O}_{3}$-dependent processes alone. The daily $\mathrm{O}_{3}$ loss rate related to iodine over the WPWP is as high as approximately 2 ppbv despite low $\mathrm{O}_{3}$ concentrations of $\sim 10 \mathrm{ppbv}$, with the loss being up to $100 \%$ greater than that without iodine. This finding suggests that warming SST driven by climate change may affect the marine atmospheric chemical balance through iodine-ozone chemistry.

\section{Introduction}

Halogens play an important role in tropospheric and stratospheric chemistry through the catalytic destruction of ozone $\left(\mathrm{O}_{3}\right)$, which affects the atmosphere's oxidizing capacity and the radiative balance of the Earth (Alicke et al., 1999; Koenig et al., 2020; Read et al., 2008; Saiz-Lopez et al., 2012; Saiz-Lopez et al., 2014; Simpson et al., 2015). Iodine, in particular, is 
30 potentially important in tropospheric chemistry because of its rapid reactions, although its concentration in the troposphere is low compared to that of chlorine and bromine. Iodine also forms aerosol particles; it can thereby affect the global radiative balance (O'Dowd et al., 2002; Sipila et al., 2016; Gómez-Martín et al., 2020; Baccarini et al., 2020; Gómez-Martín et al., 2021).

Because of their low concentrations in the atmosphere, iodine compounds are difficult to quantify. Few reports have attempted to clarify their regiona006C to global-scale sources and roles in atmospheric chemistry (Großmann et al., 2013; Mahajan et al., 2012; Prados-Roman et al., 2015a; Dix et al., 2013; Volkamer et al., 2015). In the past, the primary source of iodine in the troposphere has long been regarded as organic compounds in coastal areas (Davis et al., 1996; Carpenter et al., 2012; Prados-Roman et al., 2015a). However, results of recent studies suggest that iodine compounds over the open ocean are emitted from inorganic sources following $\mathrm{O}_{3}$ deposition over the ocean surface (Carpenter et al., 2013; Macdonald et al., 2014; Prados-Roman et al., 2015a). The inorganic sources are now regarded as the dominant emission term over the oligotrophic oceans in the global-scale chemistry-transport models representing iodine chemistry (e.g., Saiz-Lopez et al., 2014; Sekiya et al., 2020).

This study specifically examines iodine monoxide (IO) in the marine boundary layer over the open ocean from the wide latitudinal bands. Specifically, we examine processes occurring over the tropical western Pacific, where the global sea surface temperature (SST) reaches a maximum (warm pool) and where $\mathrm{O}_{3}$ minima have been reported (Rex et al., 2014; Kanaya et al., 2019; Kley et al., 1996). Actually, IO observations in environments with SSTs of $>30^{\circ} \mathrm{C}$ are limited. Observations of IO have been made in the tropics, but only for short time periods with SST > 30 $\mathrm{C}$ if any (Großmann et al., 2013; Dix et al., 2013; Prados-Roman et al., 2015a). Although the importance of halogen chemistry as a driver of $\mathrm{O}_{3}$ losses in this region has been suggested (Großmann et al., 2013; Koenig et al., 2017), this point has yet to be examined in the context of full latitudinal distributions.

The initial production of atmospheric inorganic iodine species has not been fully examined in an environment where extremely low $\mathrm{O}_{3}$ concentrations ( $<10 \mathrm{ppb}$ ) are observed. Over the Atlantic Ocean (in Cape Verde), long-term observations of iodine and ozone have been conducted, but they were in higher $\mathrm{O}_{3}$ environments of approximately 20 ppbv (Read et al., 2008). We therefore examined IO variations over the tropical western Pacific and their potential contributions to regional $\mathrm{O}_{3}$ losses, with emphasis on SST as a potential key parameter controlling the initial iodine emissions. The global SST maximum is observed in the tropical western Pacific, but observations reported from earlier studies only took place in the surrounding regions of the maximum (Großmann et al., 2013; Prados-Roman et al., 2015a). Investigation of iodine variations in the tropics is also important for elucidating the stratospheric chemical balance (Koenig et al., 2017) because transport from the troposphere to the stratosphere occurs through the Tropical Tropopause Layer (Takashima et al., 2008; Saiz-Lopez et al., 2015; Koenig et al., 2017; Holton et al., 1995). In fact, it is particularly important over the tropical western Pacific.

For this study, using the multi-axis differential optical absorption spectroscopy (MAX-DOAS) remote sensing technique, IO observations were made to quantify IO concentrations over the open ocean, covering the widest latitudinal range ever examined with a single instrument. The technique uses scattered solar radiation at several elevation angles to obtain atmospheric aerosol and gas profile concentrations (Hönninger et al., 2004; Wagner et al., 2004; Wittrock et al., 2004; Sinreich 
et al., 2005; Frieß et al., 2006; Kanaya et al., 2014). MAX-DOAS generally measures trace-gas contents over a long light path (up to 10-20 km) at low elevation angles. The long light path enables the detection of low concentrations of species of interest at near-surface altitudes. MAX-DOAS is therefore useful for quantifying low-abundance tropospheric trace gases such as IO over the open ocean.

Multi-platform measurements by MAX-DOAS from aircraft (Koenig et al., 2017; Volkamer et al., 2009) and ships (Großmann et al., 2013; Takashima et al., 2012; Volkamer et al., 2009) have been developed in recent years. Earlier studies

70 have retrieved IO concentrations (typically < 1 pptv) in the marine boundary layer over the open ocean from shipboard MAXDOAS measurements (Großmann et al., 2013; Mahajan et al., 2012; Prados-Roman et al., 2015a). Since 2008, the Japan Agency for Marine-Earth Science and Technology (JAMSTEC) has undertaken an unprecedented set of MAX-DOAS measurements on board the Research Vessels (R/Vs) Kaiyo, Mirai, and Kaimei around the world (Takashima et al., 2012). This report presents $\mathrm{IO}$ and $\mathrm{O}_{3}$ variations over the open ocean from the Arctic to the Southern hemisphere observed on RV Mirai between 2014-2018.

\section{Methodology}

\subsection{Iodine monoxide observations from ship-based MAX-DOAS measurements}

The shipboard MAX-DOAS apparatus used for this study comprised two main components: an outdoor telescope and an indoor UV-Vis spectrometer (SP-2358; Acton Research Corp., coupled to a PIXIS-400B back-illuminated CCD detector;

80 Teledyne Princeton Instruments). These were connected using a 10-14 m long fiber-optic cable (100 $\mu \mathrm{m}$ radius, 60 -core or 40-core). The telescope unit was developed jointly by the Japan Agency for Marine-Earth Science and Technology (JAMSTEC) and PREDE Co. Ltd. (Tokyo, Japan). The movable prism of the telescope unit rotates for elevation angles (ELs) of $3^{\circ}, 5^{\circ}, 10^{\circ}, 30^{\circ}$, and $90^{\circ}$. The EL is changed every minute to observe scattered sunlight. The target EL is attained by adjusting the angle of the prism actively, and by considering the angle of the ship's roll (Takashima et al., 2016). The telescope line-ofsight was off the starboard side of the ship with a field of view of approximately $1.0^{\circ}$. The spectrometer was housed in an adiabatic plastic box with the temperature held constant at $35^{\circ} \mathrm{C} \pm 0.1^{\circ} \mathrm{C}$ using a temperature controller (KT4; Panasonic Inc., Japan). The CCD was cooled to $-70^{\circ} \mathrm{C}$. The spectrometer was equipped with a 600 line $\mathrm{mm}^{-1} \mathrm{grating}$ at $300 \mathrm{~nm}$. The slit width was $100 \mu \mathrm{m}$. The typical exposure time was $0.1-0.2 \mathrm{~s}$.

Spectral data were selected for analysis when the EL was within $\pm 0.5^{\circ}$ of the target. Data were analyzed using the DOAS method (Platt and Stutz, 2008). A nonlinear least-squares spectral fitting procedure was used to derive differential slant column densities (DSCDs) of the oxygen collision complex $\left(\mathrm{O}_{2}-\mathrm{O}_{2}\right.$ or $\left.\mathrm{O}_{4}\right)$ and IO using the QDOAS software package (Danckaert et al., 2017), in which absorption cross-section data presented in Table 1 were used. For $\mathrm{O}_{4}$ and IO retrievals, $425-490 \mathrm{~nm}$ and 415-438 nm fitting windows were applied, respectively. Examples of fitting results and the time series of DSCDs are presented respectively in Figures 1 and 2. The typical fitting error of the IO DSCDs was approximately $1 \times 10^{12} \mathrm{molecules}^{-2}$, with a detection limit of approximately $4 \times 10^{12}$ molecules $\mathrm{cm}^{-2}(2 \sigma)$. 
The Mexican Maxdoas Fit (MMF) retrieval algorithm (Friedrich et al., 2019) was used for retrieval of IO profiles and vertical column densities. MMF applies the optimal estimation method and uses a two-step approach in which the aerosol profile is first retrieved from $\mathrm{O}_{4}$ DSCDs. Then, the IO profile is retrieved from the IO DSCDs using the earlier retrieved aerosol profile in the forward model. We used VLIDORT (Spurr, 2006) as the forward model in a pseudo-spherical multiple-scattering setting. Only intensity information and its analytically calculated Jacobians were used. No other Stokes parameter was used. MMF was used in logarithmic retrieval space on a retrieval grid of up to $4 \mathrm{~km}$ with $200 \mathrm{~m}$ layer height.

Both a priori profiles were constructed as constant below $500 \mathrm{~m}$ with an exponentially decreasing profile above $500 \mathrm{~m}$ for aerosol and IO profiles. The a priori aerosol optical depth was set as 0.18 . The $a$ priori IO was set to $2.5 \times 10^{12}$ molecules $\mathrm{cm}^{-2}$. The Sa matrix for both aerosol and IO retrieval was constructed using the square of $100 \%$ of the a priori profile on the diagonal and a correlation length of $200 \mathrm{~m}$. For the aerosols, the only retrieved quantity was the partial aerosol optical depth per layer. Therefore, in the forward model, a constant single scattering albedo of 0.95 was used for both retrievals: aerosol and IO. The phase function moments were constructed using the Henyey-Greenstein phase function (Henyey and Greenstein, 1941) with a constant asymmetry factor of 0.72 . The surface albedo in the forward models was set as 0.06 . The observed IO contents might be a little low compared with those from earlier studies conducted over the open ocean because of inaccuracy of the water-vapor cross-section used in earlier retrievals (Lampel et al., 2015).

\subsection{Zero-dimensional photochemical box model with iodine chemistry}

A zero-dimensional photochemical box model (Kanaya et al., 2007a; Kanaya et al., 2007b) based on the Regional Atmospheric Chemistry Mechanism (RACM) (Stockwell et al., 1997) and custom iodine chemistry was updated to include 91 chemical species and 275 reactions (reactions of iodine chemistry added to RACM are presented in Table 3 ). It was used to simulate the

115 time evolution of mixing ratios of $\mathrm{O}_{3}$ (initially $18 \mathrm{ppbv}$ ) and iodinated species in the boundary layer with assumed height of $500 \mathrm{~m}$ over the equatorial Pacific region, where the maximum concentrations of $\mathrm{IO}$ and minimum concentrations of $\mathrm{O}_{3}$ were observed. For $\mathrm{O}_{3}$, dry deposition at a velocity of $0.04 \mathrm{~cm} \mathrm{~s}^{-1}$ was considered (Pound et al., 2020). Entrainment flux of $1.2 \times$ $10^{8}$ molecules $\mathrm{cm}^{-2} \mathrm{~s}^{-1}$ was assumed for $\mathrm{NO}_{2}$, for which the initial mixing ratio was assumed to be 15 pptv. Fluxes of hypoiodous acid (HOI) and $\mathrm{I}_{2}$ from the ocean surface were estimated (Carpenter et al., 2013) as $8.4 \times 10^{7}$ and $2.6 \times 10^{6}$

120 molecules $\mathrm{cm}^{-2} \mathrm{~s}^{-1}$, respectively, at $10 \mathrm{ppbv}$ of $\mathrm{O}_{3}$, for an aqueous $\mathrm{I}^{-}$concentration of $74 \mathrm{nM}$ and wind speed of $5 \mathrm{~m} \mathrm{~s}^{-1}(8.9 \times$ $10^{7}$ molecules $\mathrm{cm}^{-2} \mathrm{~s}^{-1}$ as total HOI/I $2\left(=\mathrm{HOI}+2 \mathrm{I}_{2}\right)$ flux $)$. The $\mathrm{I}^{-}$concentration was referred from the nearest observation data at $12^{\circ} \mathrm{N}$ and $158^{\circ} \mathrm{E}$ (Tsunogai and Henmi, 1971). The assumed wind speed was from observations made during MR14-06 cruise over the region. For Case 1a, they were assumed to be linearly dependent on $\mathrm{O}_{3}$, which is consistent with Carpenter et al. (2013). For Case $1 \mathrm{~b}$ a $25 \%$ reduction of the flux was assumed, potentially because of the presence of sea-surface microlayer

125 or dissolved organic matters (Shaw and Carpenter, 2013; Tinel et al., 2020). The blue band of Figure 3 represents the range of Cases $1 \mathrm{a}$ and $1 \mathrm{~b}$, representing the case with " $\mathrm{O}_{3}$-dependent" fluxes. In Cases $2 \mathrm{a}$ and $2 \mathrm{~b}$, the $\mathrm{O}_{3}$-dependent flux in Case $1 \mathrm{a}$ was reduced to half and compensated by " $\mathrm{O}_{3}$-independent" inorganic iodine fluxes of 3.3 (or 6.6$) \times 10^{7} \mathrm{molecules}^{-2} \mathrm{~cm}^{-1}($ red band of Figure 3, representing the "quasi- $\mathrm{O}_{3}$-dependent" case). As a reference, a hypothetical case (Cases $3 \mathrm{a}$ and $\left.3 \mathrm{~b}\right)$ with 
purely " $\mathrm{O}_{3}$-independent" flux of the magnitude of 9.9 (or 13) $\times 10^{7}$ molecules $\mathrm{cm}^{-2} \mathrm{~s}^{-1}$ was also tested (orange band of Figure

1303 , representing the "purely $\mathrm{O}_{3}$-independent" case). The time-dependent simulations continued for five days with evaluation of the mixing ratio of $\mathrm{O}_{3}$ and its relation with $\mathrm{IO}$ involving daytime averages (0600-1800 ship local time) over the first to fourth days. Dry deposition velocities of iodine species (I, IO, $\mathrm{HI}, \mathrm{HOI}, \mathrm{OIO}, \mathrm{I}_{2} \mathrm{O}_{2}, \mathrm{INO}, \mathrm{INO}_{2}, \mathrm{IONO}_{2}$, and $\mathrm{I}_{2}$ ) were assumed to be 1 $\mathrm{cm} \mathrm{s}^{-1}$.

\subsection{Backward trajectory calculation}

135 The origins of airmasses over the tropical western Pacific were investigated using five-day backward trajectory calculations (Takashima et al., 2011) based on meteorological analysis data of the European Centre for Medium-range Weather Forecasts (ECMWF).

\subsection{In situ gas measurements}

For measurements of $\mathrm{O}_{3}$ and $\mathrm{CO}$, ambient air was sampled using approximately $20 \mathrm{~m}$ of Teflon tubing (6.35 mm outer

diameter) from the bow (Kanaya et al., 2019). To avoid contamination from ship exhaust, 1-min data deviated more than $1 \sigma$ of the hourly average were deleted. The $\mathrm{O}_{3}$ and $\mathrm{CO}$ concentrations were measured respectively using UV and infrared absorptions with $\mathrm{O}_{3}$ and $\mathrm{CO}$ monitors $49 \mathrm{C}$ and $48 \mathrm{C}$ (Thermo Scientific, USA). $\mathrm{O}_{3}$ concentrations observed from the R/V Mirai cruises presented in Table 3 are shown in Figure S1.

\section{Results and Discussion}

145 The IO contents (differential slant column densities (DSCDs) for an elevation angle of $3^{\circ}$ ) observed from the R/V Mirai during seven research cruises during 2014-2018 are presented in Figure 4. The cruises are presented in Table 3. Although observations were limited to some seasons and years (e.g., Arctic measurements were limited to the Northern Hemisphere summer), whole latitudinal bands were covered from $74^{\circ} \mathrm{N}$ to $67^{\circ} \mathrm{S}$, and strong latitudinal variations of IO concentrations were observed, with a maximum detected clearly in the tropics $\left(10^{\circ} \mathrm{S}-10^{\circ} \mathrm{N}\right)$, but not at higher latitudes in either hemisphere. Over Southeast Asia

150 (near Indonesia), high IO concentrations were sometimes observed near coastal areas. The highest values of up to approximately $2 \times 10^{13}$ molecules $\mathrm{cm}^{-2}$ (DSCD) were also observed in the tropical western Pacific, with wide variations at global SST maxima $\left(>30^{\circ} \mathrm{C}\right)$. From similar earlier studies (Gómez-Martín et al., 2013; Großmann et al., 2013; Mahajan et al., 2012) no data obtained under very high SST conditions over a long period were reported. Therefore, our IO observations at SST maxima (up to $31.5^{\circ} \mathrm{C}$ ) and during more than two weeks represent the most comprehensive measurements of reactive iodine over the tropical Western Pacific warm pool (WPWP).

Specifically regarding IO variations over the tropical western Pacific, we found IO contents (vertical column densities (VCDs)) of approximately $0.7-1.8 \times 10^{12}$ molecules $\mathrm{cm}^{-2}$ (Figure 5). Five-day backward trajectories indicate that air masses in this region originated from the open ocean (Figure 5). The carbon monoxide (CO) content was constantly low (60 ppbv, 
Figure 6), which is also consistent with an air mass originating from the open ocean. In addition, the chlorophyll content, based on satellite MODIS measurements (NASA Level-3 ver. 2018) in the source region, was also low (Figure 5), implying that any organic source of iodine is expected to be negligible. The IO data collected over the tropical western Pacific are consistent with $\mathrm{I}^{-}$variations reported in earlier studies (Chance et al., 2014; Chance et al., 2019; Sherwen et al., 2016), showing an increase of $\mathrm{I}^{-}$concentration with SST.

For the time series of IO concentrations near the ocean surface (0-200 m height, Figure 7), the values ranged from approximately $0.3-0.8 \mathrm{pptv}$, with wide variations over a timescale of a few days. The IO concentration near the surface depends on the shape of the a priori profile used for the retrieval, but day-to-day variations near the surface were unaffected by the choice of profile. Insufficient data were retrieved to document diurnal IO variations accurately. At times, the $\mathrm{O}_{3}$ concentrations were generally low ( $<20 \mathrm{ppbv}$ ) and extremely low ( $<10 \mathrm{ppbv}$ ) (Figure 7). One unique finding was that, even under low- $\mathrm{O}_{3}$ conditions, negative correlation was found between $\mathrm{IO}$ and $\mathrm{O}_{3}$ concentrations in the daily dataset (Figures 3 and 7). Laboratory studies indicate that high $\mathrm{O}_{3}$ concentrations can cause emission of iodine from ocean to atmosphere (Carpenter et al., 2013; Macdonald et al., 2014; Sakamoto et al., 2009). This “ $\mathrm{O}_{3}$-dependent” iodine release has been regarded as being more dominant than other " $\mathrm{O}_{3}$-independent" types of emission, including photo-labile iodocarbons such as $\mathrm{CH}_{2} \mathrm{I}_{2}, \mathrm{CH}_{2} \mathrm{ICl}$, and their subsequent photolysis over the open oceans in every global-scale chemistry transport model representing iodine chemistry (Saiz-Lopez et al., 2014; Sekiya et al., 2020; Sherwen et al., 2016). However, with an " $\mathrm{O}_{3}$-dependent" $\mathrm{HOI} / \mathrm{I}_{2}$ flux of approximately $9 \times 10^{7}$ molecules $\mathrm{cm}^{-2} \mathrm{~s}^{-1}$ (section 2.2), as expected under an $\mathrm{O}_{3}$ mixing ratio of approximately 10 ppbv, a zero-dimensional box model was not able to reproduce the negative correlation found between $\mathrm{IO}$ and $\mathrm{O}_{3}$. Because the initial $\mathrm{HOI} / \mathrm{I}_{2}$ release flux limited by $\mathrm{O}_{3}$ in the $<12$ ppbv mixing-ratio range cannot drive the strong $\mathrm{O}_{3}$ reduction, the scenario produced only a positive correlation (Case 1, Figure 3). In contrast, another case in which the " $\mathrm{O}_{3}$-independent" flux was added to compensate for the " $\mathrm{O}_{3}$-dependent" term weakened by a factor of 2 (Case 2, Figure 3) better reproduced the observed trend.

180 The weakened flux might be explained by dissolved organic carbon (Shaw and Carpenter, 2013) or the presence of a seasurface microlayer (Tinel et al., 2020) impeding iodine vaporization. The added " $\mathrm{O}_{3}$-independent" flux is not explainable solely by flux from photolyses of iodocarbons within the marine boundary layer (approximately $10^{7}$ molecules $\mathrm{cm}^{-2} \mathrm{~s}^{-1}$ ) generally assumed in the three-dimensional models (Saiz-Lopez et al., 2014; Sekiya et al., 2020; Sherwen et al., 2016). It therefore necessitates a survey of missing sources. The third case, with only an " $\mathrm{O}_{3}$-independent" flux (Case 3, Figure 3) might explain the negative correlation more easily, whereas the total change of the flux type not being simply supported. We therefore hypothesize that $\mathrm{O}_{3}$-independent processes are more important than has been represented by recent models. Indeed, a larger magnitude of organic iodine flux (approximately $7 \times 10^{7}$ molecules $\mathrm{cm}^{-2} \mathrm{~s}^{-1}$ ) was reported in the low-latitude Pacific (Großmann et al., 2013), and would therefore be the most likely cause of the negative correlation. However, that study (Großmann et al., 2013) relied on assumption of an even larger inorganic iodine emission flux to explain the observed IO 190 concentrations. Therefore, our analysis is the first to suggest that the " $\mathrm{O}_{3}$-independent" flux can be comparably important to the " $\mathrm{O}_{3}$-dependent" flux in this region. Other $\mathrm{O}_{3}$-independent iodine release mechanisms such as photooxidation of aqueous $\mathrm{I}^{-}$ (Watanabe et al., 2019) might also be worth exploring. The modelled net $\mathrm{O}_{3}$ loss rate due to iodine in Case 2 increased by up 
to $100 \%$ over that without iodine. The $\mathrm{O}_{3}$ loss rate in the iodine cycle in Case 2 increased by approximately $15 \%$ over that in Case 1 (Table 4).

The expectation that a positive correlation between $\mathrm{O}_{3}$ and $\mathrm{IO}$ would occur with $\mathrm{O}_{3}$-dependent processes over a low $\mathrm{O}_{3}$ concentration range was also confirmed using three-dimensional global chemistry-transport models including halogen chemistry (Sekiya et al., 2020; Saiz-Lopez et al., 2014) over the tropical western Pacific (Figures S2, S3). An alternative explanation of the observed negative correlation would be the mixing of air masses experiencing different degrees of iodine chemistry. If so, such negative correlation could appear in the chemistry-transport model results. However, this feature was not found and therefore we propose an " $\mathrm{O}_{3}$-independent" flux. Over the Atlantic, the $\mathrm{O}_{3}$ mixing ratio rarely reaches these low levels (10 ppbv or less). Therefore such process analyses have not been undertaken there. Under the influence of " $\mathrm{O}_{3}$ independent" sources, even lower $\mathrm{O}_{3}$ concentrations would be attainable. Radiative forcing of $\mathrm{O}_{3}$, as estimated recently with halogen chemistry (Sherwen et al., 2017; Iglesias-Suarez et al., 2020; Saiz-Lopez et al., 2012; Hossaini et al., 2015), might be influenced by the dependence of iodine flux on $\mathrm{O}_{3}$ concentration, which might play a major role in estimating past and future concentrations of $\mathrm{O}_{3}$.

The time series of meteorological parameters including wind speed and SST was also investigated, but no clear correlation with $\mathrm{O}_{3}$ or IO concentration was found on a timescale of a few days (Figure 6). An earlier study (Kanaya et al., 2019) investigating the diurnal variation of $\mathrm{O}_{3}$ in this area based on a comparison of observational data and a chemical transport model indicated that an as-yet-unidentified $\mathrm{O}_{3}$ loss might occur over the tropical western Pacific. Our results imply that iodine chemistry plays an important role in $\mathrm{O}_{3}$ loss in the area of SST maxima, which is regarded as an entry point from the troposphere to stratosphere. Moreover, these results provide insights into the manner by which increasing SST associated with climate change might modify the marine atmospheric chemical balance, which warrants further investigation.

\section{Summary}

In this study, shipboard multi-axis differential optical absorption spectroscopy (MAX-DOAS), a remote sensing technique, was used during seven research cruises covering the widest latitudinal bands from the Arctic to the Southern Hemisphere as ever made with a single instrument, spanning SSTs of approximately $0^{\circ} \mathrm{C}$ to $31.5^{\circ} \mathrm{C}$, allowing investigation of the variation of IO concentrations. IO was detected at low latitudes. It was particularly abundant over the tropical western Pacific (warm pool), appearing as an "iodine fountain", where SST maxima $\left(>30^{\circ} \mathrm{C}\right)$ and $\mathrm{O}_{3}$ minima are observed.

We report negative correlation between $\mathrm{IO}$ and $\mathrm{O}_{3}$ concentrations over the $\mathrm{IO}$ maximum, even under extremely low $\mathrm{O}_{3}$ conditions, which few earlier studies have demonstrated. This correlation is not explained easily by the $\mathrm{O}_{3}$-dependent oceanic fluxes of photolabile inorganic iodine compounds adopted for recent simulation studies. Our findings rather imply that " $\mathrm{O}_{3}$ independent" pathways which release iodine compounds from the ocean are also important. Iodine input to the atmosphere from the ocean surface is greater in areas of higher SST, leading to an "iodine fountain" in the Western Pacific warm pool because the $\mathrm{I}^{-}$concentration in the ocean surface is likely to be higher in these areas. This higher concentration might contribute to more pronounced $\mathrm{O}_{3}$ destruction over the Western Pacific warm pool than estimated earlier. Warming SSTs associated with 
climate change can change the atmospheric chemical balance through halogen chemistry, warranting further quantitative investigation.

Table 1: Cross-sections of iodine monoxide (IO) and $\mathrm{O}_{4}$ differential slant column densities used for this study

\begin{tabular}{|c|c|c|}
\hline & Component & Reference \\
\hline \multirow{4}{*}{$\mathrm{IO}$} & $\mathrm{NO}_{2}$ & Vandaele et al. (1998) \\
\hline & $\mathrm{O}_{3}$ & Bogumil et al. (2000) \\
\hline & $\mathrm{H}_{2} \mathrm{O}$ & HITEMP* (Rothman et al., 2013) \\
\hline & $\mathrm{IO}$ & Gómez-Martín et al. (2005) \\
\hline \multirow{4}{*}{$\mathrm{O}_{4}$} & $\mathrm{NO}_{2}$ & Vandaele et al. (1998) \\
\hline & $\mathrm{O}_{3}$ & Bogumil et al. (2000) \\
\hline & $\mathrm{H}_{2} \mathrm{O}$ & HITEMP (Rothman et al., 2013) \\
\hline & $\mathrm{O}_{4}$ & Thalman and Volkamer (2013) \\
\hline
\end{tabular}

* Correction factors from Lampel et al. (2015) were applied.

Table 2: Reactions of iodine chemistry added to RACM

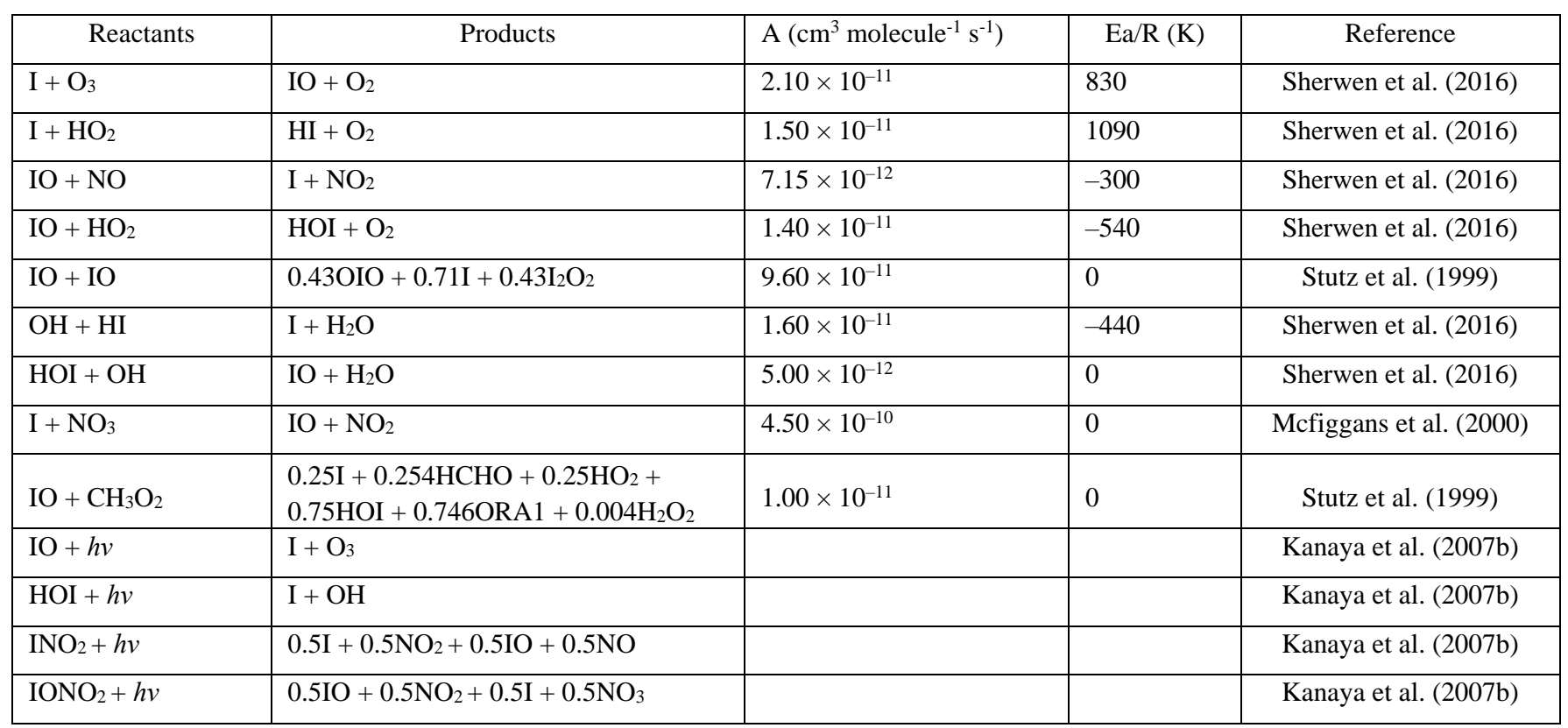


https://doi.org/10.5194/acp-2021-680

Preprint. Discussion started: 18 August 2021

(C) Author(s) 2021. CC BY 4.0 License.
Atmospheric

Chemistry

and Physics

Discussions

\begin{tabular}{|c|c|c|c|c|}
\hline $\mathrm{OIO}+\mathrm{OH}$ & $\mathrm{HOI}+\mathrm{O}_{2}$ & $7.00 \times 10^{-12}$ & 0 & Kanaya et al. (2007b) \\
\hline $\mathrm{I}_{2} \mathrm{O}_{2}+h v$ & $\mathrm{I}+\mathrm{OIO}$ & & & Kanaya et al. (2007b) \\
\hline $\mathrm{I}+\mathrm{NO}_{2}(+\mathrm{M})$ & $\mathrm{INO}_{2}(+\mathrm{M})$ & $5.40 \times 10^{-12}$ & 0 & Kanaya et al. (2003) \\
\hline $\mathrm{INO}_{2}$ & $\mathrm{I}+\mathrm{NO}_{2}$ & $9.94 \times 10^{+17}$ & 11859 & Sherwen et al. (2016) \\
\hline $\mathrm{IO}+\mathrm{NO}_{2}(+\mathrm{M})$ & $\mathrm{IONO}_{2}(+\mathrm{M})$ & $3.70 \times 10^{-12}$ & 0 & Kanaya et al. (2003) \\
\hline $\mathrm{IONO}_{2}$ & $\mathrm{IO}+\mathrm{NO}_{2}$ & $2.10 \times 10^{+15}$ & 13670 & Sherwen et al. (2016) \\
\hline $\mathrm{I}+\mathrm{NO}(+\mathrm{M})$ & INO $(+\mathrm{M})$ & $4.10 \times 10^{-13}$ & 0 & Kanaya et al. (2003) \\
\hline INO & $\mathrm{I}+\mathrm{NO}$ & $1.40 \times 10^{-1}$ & 0 & Kanaya et al. (2003) \\
\hline $\mathrm{OIO}+\mathrm{NO}$ & $\mathrm{IO}+\mathrm{NO}_{2}$ & $1.10 \times 10^{-12}$ & -542 & Sherwen et al. (2016) \\
\hline $\mathrm{IO}+\mathrm{ISOP}$ & $\begin{array}{l}0.25 \mathrm{I}+0.132 \mathrm{MACR}+0.855 \mathrm{OLT}+ \\
0.25 \mathrm{HO}_{2}+0.179 \mathrm{HCHO}+0.75 \mathrm{HOI}+ \\
0.075 \mathrm{H}_{2} \mathrm{O}_{2}+0.9 \mathrm{OH}\end{array}$ & $1.00 \times 10^{-11}$ & 0 & Kanaya et al. (2007b) \\
\hline $\mathrm{IBr}+h v$ & I & & & Kanaya et al. (2007b) \\
\hline $\mathrm{OIO}+h v$ & $\mathrm{I}+\mathrm{O}_{2}$ & & & Kanaya et al. (2007c) \\
\hline $\mathrm{I}_{2}+\mathrm{OH}$ & $\mathrm{HOI}+\mathrm{I}$ & $2.10 \times 10^{-10}$ & & Sherwen et al. (2016) \\
\hline $\mathrm{I}_{2}+\mathrm{NO}_{3}$ & $\mathrm{I}+\mathrm{IONO}_{2}$ & $1.50 \times 10^{-12}$ & & Sherwen et al. (2016) \\
\hline $\mathrm{I}_{2}+h v$ & $2 \mathrm{I}$ & & & Alicke et al. (1999) \\
\hline $\mathrm{IO}+\mathrm{OIO}$ & $\mathrm{I}_{2} \mathrm{O}_{3}$ & $1.5 \times 10^{-10}$ & & Sherwen et al. (2016) \\
\hline $\mathrm{OIO}+\mathrm{OIO}$ & $\mathrm{I}_{2} \mathrm{O}_{4}$ & $1.5 \times 10^{-10}$ & & Sherwen et al. (2016) \\
\hline $\mathrm{I}_{2} \mathrm{O}_{2}$ & $\mathrm{OIO}+\mathrm{I}$ & 1.13 & & Saiz-Lopez et al. (2016) \\
\hline $\mathrm{I}_{2} \mathrm{O}_{2}$ & $\mathrm{IO}+\mathrm{IO}$ & 0.00532 & & Saiz-Lopez et al. (2016) \\
\hline $\mathrm{I}_{2} \mathrm{O}_{4}$ & $\mathrm{OIO}+\mathrm{OIO}$ & 0.0879 & & Saiz-Lopez et al. (2016) \\
\hline $\mathrm{HOI}+\mathrm{NO}_{3}$ & $\mathrm{IO}+\mathrm{HNO}_{3}$ & $2.7 \times 10^{-12} \times(300 / \mathrm{T})^{2.66}$ & & Saiz-Lopez et al. (2016) \\
\hline $\mathrm{I}_{2} \mathrm{O}_{3}+h v$ & $\mathrm{IO}+\mathrm{OIO}$ & & & Saiz-Lopez et al. (2016) \\
\hline $\mathrm{I}_{2} \mathrm{O}_{4}+h v$ & $\mathrm{OIO}+\mathrm{OIO}$ & & & Saiz-Lopez et al. (2016) \\
\hline
\end{tabular}

Table 3: Research cruises of the R/V Mirai that generated data used for this study

\begin{tabular}{lcc}
\hline \multicolumn{1}{c}{ Cruise } & Period & Area \\
\hline MR14-06 (leg 1) & 8 Nov - 3 Dec, 2014 & Western Pacific, Tropics \\
\hline MR15-04 & 6 Nov - 21 Nov, 2015 & Western Pacific, East Indian Ocean \\
\hline MR15-05 (leg 2) & 14 Jan - 24 Jan, 2016 & Western Pacific \\
\hline MR16-06 & 24 Aug -4 Oct, 2016 & Arctic Ocean, Bering Sea, North Pacific \\
\hline MR16-09 (leg 3) & 8 Feb - 3 Mar, 2017 & Southern Ocean \\
\hline
\end{tabular}


https://doi.org/10.5194/acp-2021-680

Preprint. Discussion started: 18 August 2021

(c) Author(s) 2021. CC BY 4.0 License.

\begin{tabular}{lcc}
\hline MR17-05C & 25 Aug - 29 Sep, 2017 & Arctic Ocean, Bering Sea, North Pacific \\
\hline MR17-08 & 22 Nov, 2017 - 17 Jan 2018 & Western Pacific, East Indian Ocean \\
\hline
\end{tabular}

Table 4. Net and process-specific $\mathrm{O}_{3}$ loss rates in three cases at an $\mathrm{O}_{3}$ concentration of 10 ppbv, as calculated by the box model

\begin{tabular}{|c|c|c|c|c|}
\hline & IO [ppbv] & net loss [ppbv d $\left.{ }^{-1}\right]$ & HOx/Ox cycle loss [ppbv d $\left.{ }^{-1}\right]$ & Iodine cycle loss [ppbv d $\left.{ }^{-1}\right]$ \\
\hline w.o. iodine & 0 & -1.06 & -1.64 & 0 \\
\hline Case 1 & $0.553-0.741$ & $-1.85--2.08$ & -1.62 & $-0.519--0.720$ \\
\hline Case 2 & $0.611-0.851$ & $-1.92--2.21$ & -1.62 & $-0.579--0.844$ \\
\hline Case 3 & $0.723-0.960$ & $-2.05--2.34$ & $-0.700--0.967$ \\
\hline
\end{tabular}


2 Dec 2014, 1:47UTC, SZA=17.24잉
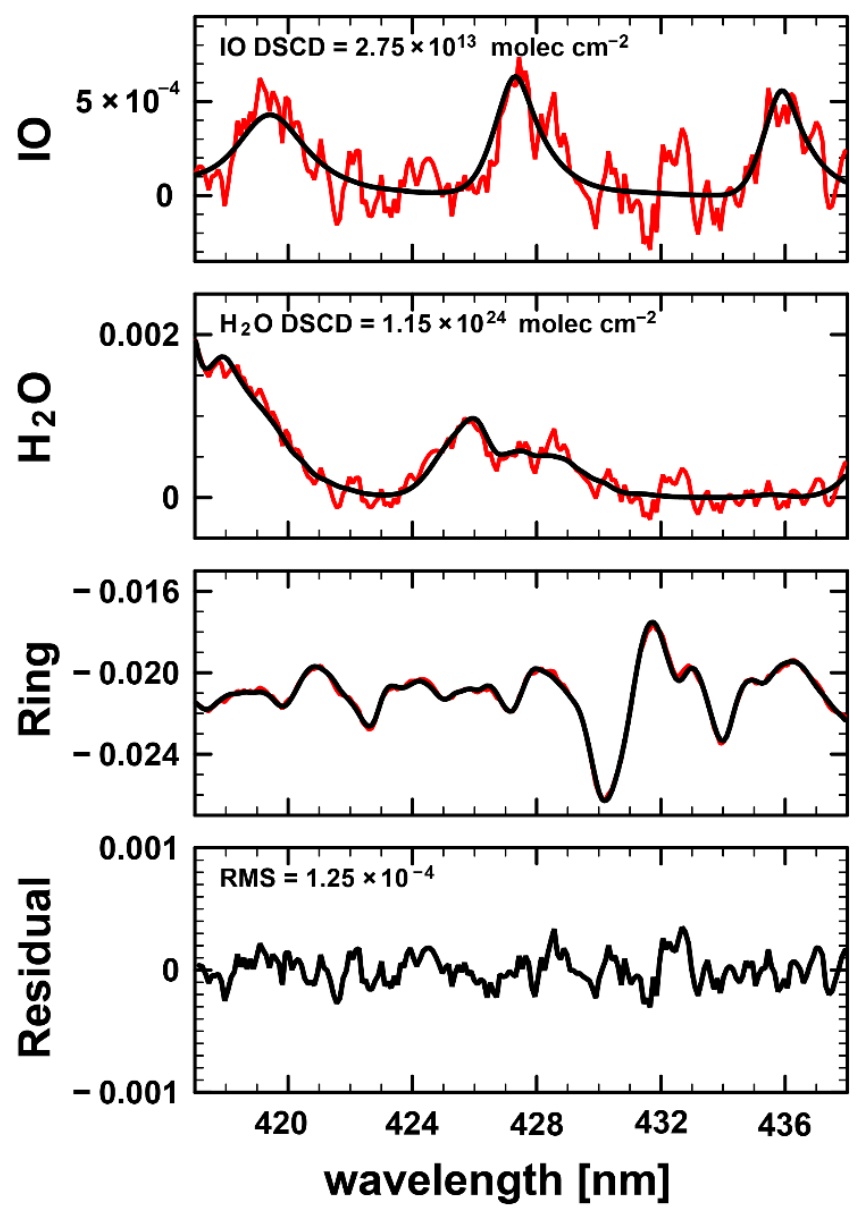

Figure 1: Nonlinear least-squares spectral fitting results for IO concentrations observed on 2 December 2014. The top two panels show fitting for IO and $\mathrm{H}_{2} \mathrm{O}$. Black lines represent the cross-section scaled to the spectrum (red) determined by differential optical absorption spectroscopy. The lower two panels show the Ring-effect contribution and the residual spectrum. 


\section{DSCDs [MR14], 20141202 (UTC)}

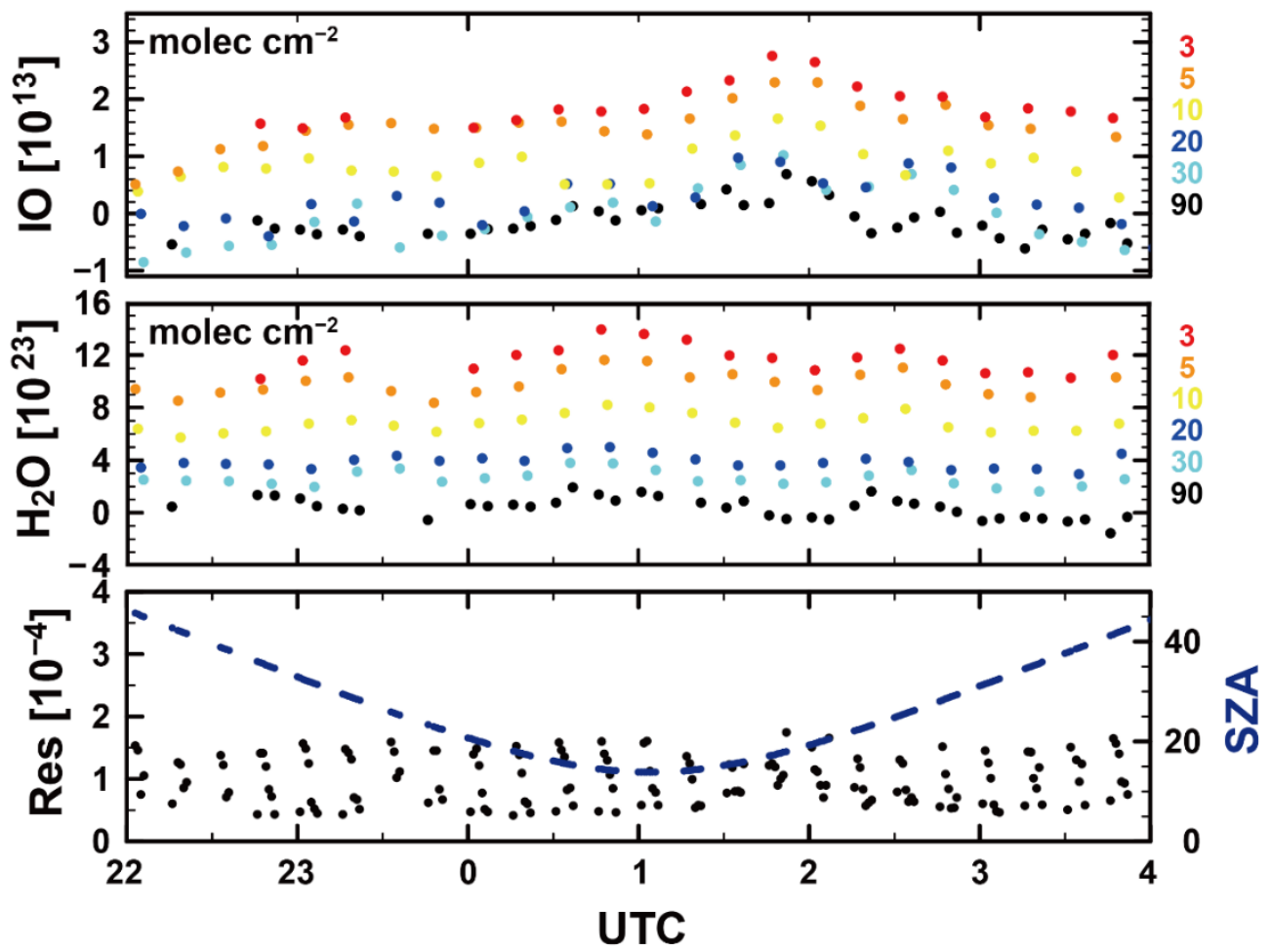

Figure. 2: Time series of $\mathrm{IO}$ and $\mathrm{H}_{2} \mathrm{O}$ differential slant column densities (DSCDs) for elevation angles of $3^{\circ}, 5^{\circ}, 10^{\circ}, 20^{\circ}, 30^{\circ}$, and $90^{\circ}$; RMS residual; and the solar zenith angle observed on 1-2 December 2014 over the tropical western Pacific. 
https://doi.org/10.5194/acp-2021-680

Preprint. Discussion started: 18 August 2021

(c) Author(s) 2021. CC BY 4.0 License.

(c) (i)
Atmospheric

Chemistry

and Physics

Discussions

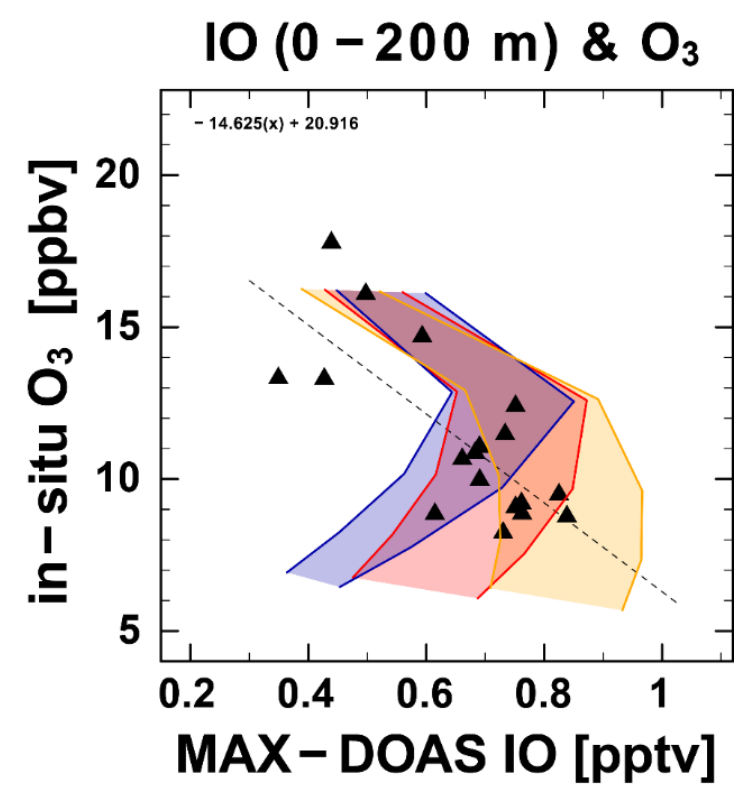

Figure 3: Daily median IO mixing ratio for 0-200 m (pptv) concentrations observed by MAX-DOAS versus daily median in situ ozone mixing ratio (ppbv). Results of box-model simulations with "O $\mathrm{O}_{3}$-dependent" (Case 1), "quasi-O $\mathrm{O}_{3}$-dependent” (Case 2), and "pure $\mathrm{O}_{3}$

235 independent" (Case 3) emission fluxes of iodine compounds are superimposed respectively as blue-, red-, and orange-shaded areas. 


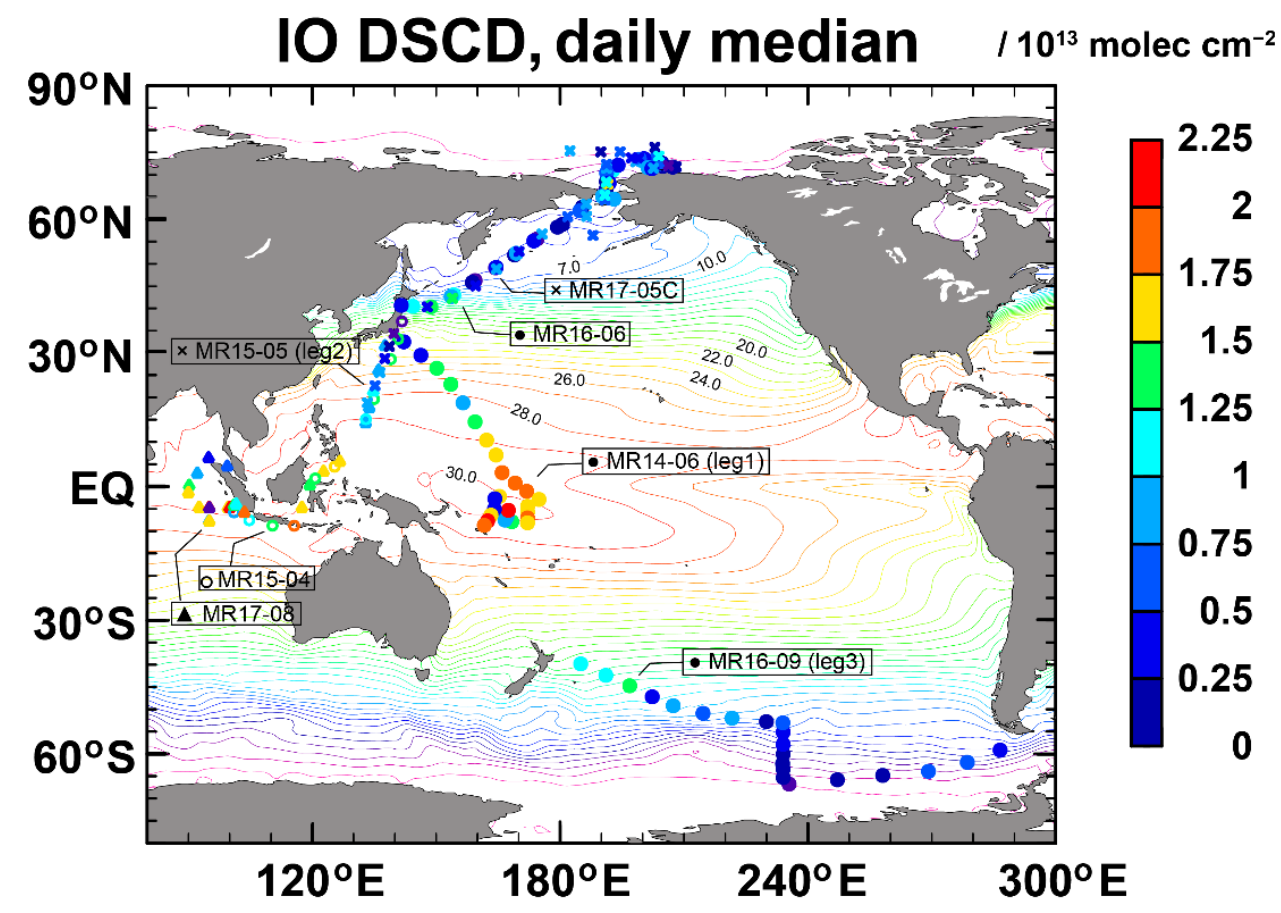

Figure 4: Daily median IO content (differential slant column densities (DSCD) for an elevation angle of $3^{\circ}$; molecules $\mathrm{cm}^{-2}$ ) observed from the R/V Mirai during 2014-2018. Color contours represent the optimum interpolated SST averaged for 2014-2018. 


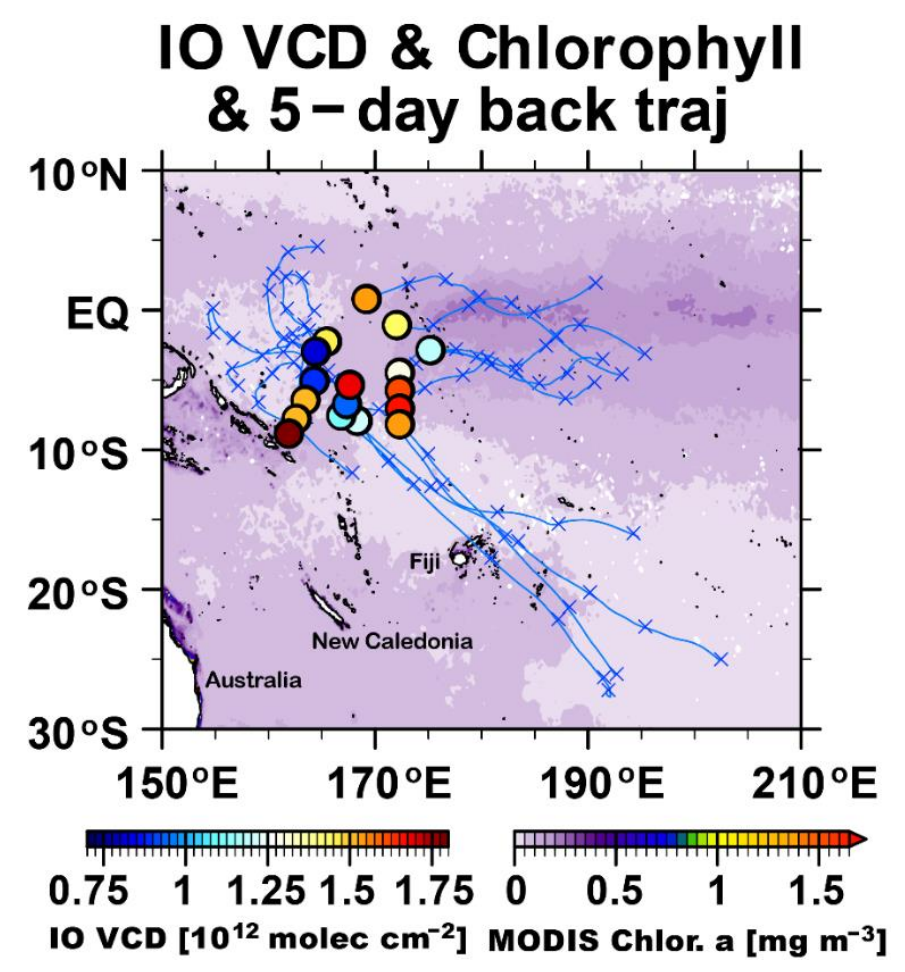

Figure 5: Daily median tropospheric IO vertical column densities (VCDs, molecules $\mathrm{cm}^{-2}$ ) observed from the R/V Mirai during 16 November to 2 December 2014 and chlorophyll-a concentrations observed via satellite (MODIS). Blue crosses and lines represent five-day backward trajectories. 


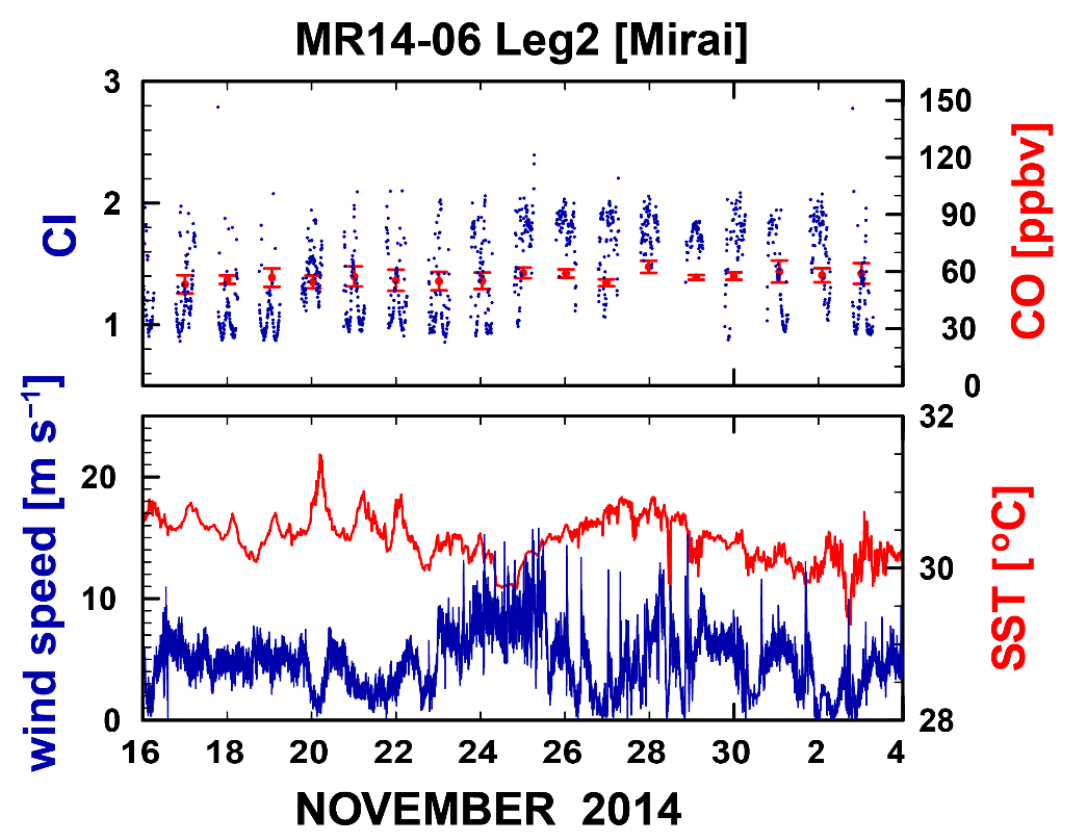

Figure 6: Time series of the $\mathrm{CO}$ mixing ratio [ppbv], color index (CI; defined as the ratio of the measured intensities at the two wavelengths of 500 and $380 \mathrm{~nm}$ (Takashima et al., 2009)), wind speed $\left(\mathrm{m} \mathrm{s}^{-1}\right)$, and SST $\left({ }^{\circ} \mathrm{C}\right)$. 


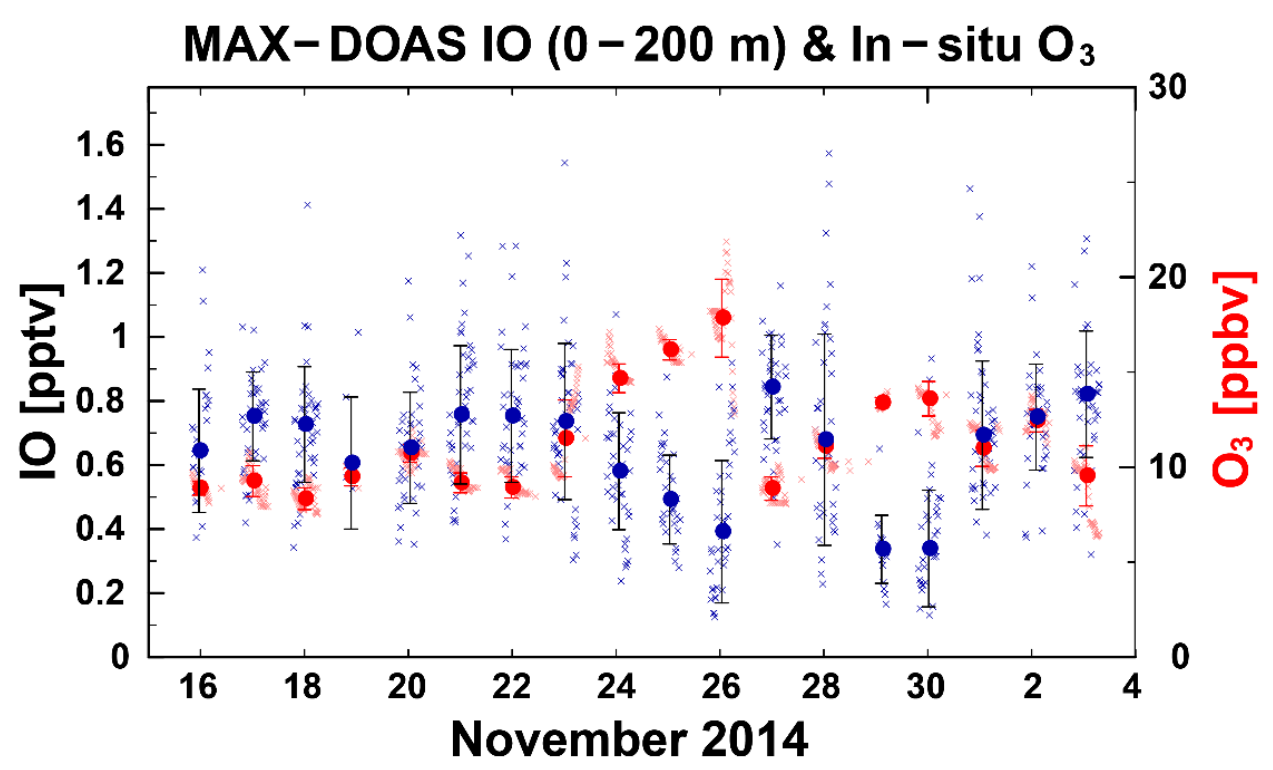

Figure 7: Time series of IO mixing ratio for 0-200 m (blue, pptv) observed by MAX-DOAS, and in situ $\mathrm{O}_{3}$ mixing ratio (red, ppbv). Circles and horizontal bars respectively represent the daily median and one standard deviation. 


\section{Author contributions}

HT designed the study, conducted shipboard MAX-DOAS observations and analyses, and wrote the manuscript. YKa proposed the research concept, supported the MAX-DOAS observations, and conducted $\mathrm{O}_{3} / \mathrm{CO}$ observations and 0-D box model calculations. KS supported the observations and analysis. MF conducted the retrieval of IO profiles and IO VCDs. MV supported the DOAS analysis. FT, TM, and YKo supported the MAX-DOAS observations. CAC, AS-L, and TS conducted a simulation using a global chemical model. All co-authors provided comments to improve the manuscript.

\section{Supplement}

Supporting information accompanies this paper.

\section{Acknowledgments}

We thank K. Kruger, Y. Yamashita, and K. Hara for their useful comments. We also thank Robert Spurr for free use of the VLIDORT radiative transfer code package. DOAS analysis involved the QDOAS software. We used MODIS chlorophyll $a$, OI SST, and ECMWF meteorological data. Figures were produced using the GFD-Dennou Library. This work was supported in part by funding from Fukuoka University (Grant No. 197103). This study has also received funding from the European

265 Research Council Executive Agency under the European Union's Horizon 2020 Research and Innovation programme (Project 'ERC-2016-COG 726349 CLIMAHAL').

\section{References}

Alicke, B., Hebestreit, K., Stutz, J., and Platt, U.: Iodine oxide in the marine boundary layer, Nature, 397, 572-573, Doi 10.1038/17508, 1999.

Baccarini, A., Karlsson, L., Dommen, J., Duplessis, P., Vullers, J., Brooks, I. M., Saiz-Lopez, A., Salter, M., Tjernstrom, M., Baltensperger, U., Zieger, P., and Schmale, J.: Frequent new particle formation over the high Arctic pack ice by enhanced iodine emissions, Nat Commun, 11, 10.1038/s41467-020-18551-0, 2020.

Bogumil, K., Orphal, J., and Burrows, J. P.: Temperature-dependent absorption cross-sections of $\mathrm{O}_{3}, \mathrm{NO}_{2}$, and other atmospheric trace gases measured using the SCIAMACHY spectrometer, Proceedings of the ERS-Envisat Symposium, 2000.

Carpenter, L. J., Archer, S. D., and Beale, R.: Ocean-atmosphere trace gas exchange, Chem Soc Rev, 41, 6473-6506, $10.1039 / \mathrm{c} 2 \mathrm{cs} 35121 \mathrm{~h}, 2012$. 
Carpenter, L. J., MacDonald, S. M., Shaw, M. D., Kumar, R., Saunders, R. W., Parthipan, R., Wilson, J., and Plane, J. M. C.: Atmospheric iodine levels influenced by sea surface emissions of inorganic iodine, Nat Geosci, 6, 108-111, 10.1038/Ngeo1687, 2013.

Chance, R., Baker, A. R., Carpenter, L., and Jickells, T. D.: The distribution of iodide at the sea surface, Environ Sci-Proc Imp, 16, 1841-1859, 10.1039/c4em00139g, 2014.

Chance, R. J., Tinel, L., Sherwen, T., Baker, A. R., Bell, T., Brindle, J., Campos, M., Croot, P., Ducklow, H., Peng, H., Hopkins, F., Hoogakker, B., Hughes, C., Jickells, T. D., Loades, D., Macaya, D. A. R., Mahajan, A. S., Malin, G., Phillips, D., Roberts, I., Roy, R., Sarkar, A., Sinha, A. K., Song, X., Winkelbauer, H., Wuttig, K., Yang, M., Peng, Z., and Carpenter, L. J.: Global sea-surface iodide observations, 1967-2018, Sci Data, 6, 286, 10.1038/s41597-019-0288-y, 2019.

Danckaert, T., Fayt, C., Van Roozendael, M., De Smedt, I., Letocart, V., Merlaud, A., and Pinardi, G.: QDOAS software user manual, Belgian Institute for Space Aeronomy2017.

Davis, D., Crawford, J., Liu, S., McKeen, S., Bandy, A., Thornton, D., Rowland, F., and Blake, D.: Potential impact of iodine on tropospheric levels of ozone and other critical oxidants, J Geophys Res-Atmos, 101, 2135-2147, Doi 10.1029/95jd02727, 1996.

Dix, B., Baidara, S., Bresch, J. F., Hall, S. R., Schmidt, K. S., Wang, S. Y., and Volkamer, R.: Detection of iodine monoxide in the tropical free troposphere, P Natl Acad Sci USA, 110, 2035-2040, 10.1073/pnas.1212386110, 2013.

Friedrich, M. M., Rivera, C., Stremme, W., Ojeda, Z., Arellano, J., Bezanilla, A., Garcia-Reynoso, J. A., and Grutter, M.: $\mathrm{NO}_{2}$ vertical profiles and column densities from MAX-DOAS measurements in Mexico City, Atmos Meas Tech, 12, 25452565, 10.5194/amt-12-2545-2019, 2019.

Frieß, U., Monks, P. S., Remedios, J. J., Rozanov, A., Sinreich, R., Wagner, T., and Platt, U.: MAX-DOAS O 4 measurements: A new technique to derive information on atmospheric aerosols: 2. Modeling studies, Journal of Geophysical Research, 111, 10.1029/2005jd006618, 2006.

Gómez-Martín, J. C., Spietz, P., and Burrows, J. P.: Spectroscopic studies of the I-2/O-3 photochemistry - Part 1: Determination of the absolute absorption cross sections of iodine oxides of atmospheric relevance, J Photoch Photobio A, 176, 15-38, 10.1016/j.jphotochem.2005.09.024, 2005.

Gómez-Martín, J. C., Lewis, T. R., Blitz, M. A., Plane, J. M. C., Kumar, M., Francisco, J. S., and Saiz-Lopez, A.: A gas-toparticle conversion mechanism helps to explain atmospheric particle formation through clustering of iodine oxides, Nat Commun, 11, 4521, 10.1038/s41467-020-18252-8, 2020.

Gómez-Martín, J. C., Saiz-Lopez, A., Cuevas, C. A., Fernandez, R. P., Gilfedder, B. S., Weller, R., Baker, A. R., Droste, E., and Lai, S.: Spatial and temporal variability of iodine in aerosol, J Geophys Res-Atmos, 126, 10.1002/essoar.10505416.1, 2021.

Gómez-Martín, J. C., Mahajan, A. S., Hay, T. D., Prados-Román, C., Ordóñez, C., MacDonald, S. M., Plane, J. M., Sorribas, M., Gil, M., and Paredes Mora, J. F.: Iodine chemistry in the eastern Pacific marine boundary layer, Journal of Geophysical Research: Atmospheres, 118, 887-904, 2013. 
Großmann, K., Frieß, U., Peters, E., Wittrock, F., Lampel, J., Yilmaz, S., Tschritter, J., Sommariva, R., von Glasow, R., Quack, B., Krüger, K., Pfeilsticker, K., and Platt, U.: Iodine monoxide in the Western Pacific marine boundary layer, Atmos Chem Phys, 13, 3363-3378, 10.5194/acp-13-3363-2013, 2013.

Henyey, L. G. and Greenstein, J. L.: Diffuse radiation in the Galaxy, Astrophys J, 93, 70-83, 10.1086/144246, 1941.

Holton, J. R., Haynes, P. H., Mcintyre, M. E., Douglass, A. R., Rood, R. B., and Pfister, L.: Stratosphere-Troposphere Exchange, Rev Geophys, 33, 403-439, Doi 10.1029/95rg02097, 1995.

Hönninger, G., von Friedeburg, C., and Platt, U.: Multi axis differential optical absorption spectroscopy (MAX-DOAS), Atmos Chem Phys, 4, 231-254, DOI 10.5194/acp-4-231-2004, 2004.

Hossaini, R., Chipperfield, M. P., Montzka, S. A., Rap, A., Dhomse, S., and Feng, W.: Efficiency of short-lived halogens at influencing climate through depletion of stratospheric ozone, Nat Geosci, 8, 186-190, 10.1038/Ngeo2363, 2015.

Iglesias-Suarez, F., Badia, A., Fernandez, R. P., Cuevas, C. A., Kinnison, D. E., Tilmes, S., Lamarque, J. F., Long, M. C., Hossaini, R., and Saiz-Lopez, A.: Natural halogens buffer tropospheric ozone in a changing climate, Nat Clim Change, 10, 147-154, 10.1038/s41558-019-0675-6, 2020.

Kanaya, Y., Kajii, Y., and Akimoto, H.: Solar actinic flux and photolysis frequency determinations by radiometers and a radiative transfer model at Rishiri Island: comparisons, cloud effects, and detection of an aerosol plume from Russian forest fires, Atmos Environ, 37, 2463-2475, 10.1016/S1352-2310(03)00183-3, 2003.

Kanaya, Y., Cao, R. Q., Akimoto, H., Fukuda, M., Komazaki, Y., Yokouchi, Y., Koike, M., Tanimoto, H., Takegawa, N., and Kondo, Y.: Urban photochemistry in central Tokyo: 1. Observed and modeled $\mathrm{OH}$ and $\mathrm{HO}_{2}$ radical concentrations during the winter and summer of 2004, J Geophys Res-Atmos, 112, 10.1029/2007jd008670, 2007a.

Kanaya, Y., Tanimoto, H., Matsumoto, J., Furutani, H., Hashimoto, S., Komazaki, Y., Tanaka, S., Yokouchi, Y., Kato, S., Kajii, Y., and Akimoto, $\mathrm{H}$. : Diurnal variations in $\mathrm{H}_{2} \mathrm{O}_{2}, \mathrm{O}_{3}, \mathrm{PAN}, \mathrm{HNO}_{3}$ and aldehyde concentrations and $\mathrm{NO} / \mathrm{NO}_{2}$ ratios at Rishiri Island, Japan: Potential influence from iodine chemistry, Sci Total Environ, 376, 185-197, 10.1016/j.scitotenv.2007.01.073, 2007b.

335 Kanaya, Y., Miyazaki, K., Taketani, F., Miyakawa, T., Takashima, H., Komazaki, Y., Pan, X. L., Kato, S., Sudo, K., Sekiya, T., Inoue, J., Sato, K., and Oshima, K.: Ozone and carbon monoxide observations over open oceans on R/V Mirai from 67 degrees S to 75 degrees N during 2012 to 2017: testing global chemical reanalysis in terms of Arctic processes, low ozone levels at low latitudes, and pollution transport, Atmos Chem Phys, 19, 7233-7254, 10.5194/acp-19-7233-2019, 2019.

340 Kanaya, Y., Irie, H., Takashima, H., Iwabuchi, H., Akimoto, H., Sudo, K., Gu, M., Chong, J., Kim, Y. J., Lee, H., Li, A., Si, F., Xu, J., Xie, P. H., Liu, W. Q., Dzhola, A., Postylyakov, O., Ivanov, V., Grechko, E., Terpugova, S., and Panchenko, M.: Long-term MAX-DOAS network observations of $\mathrm{NO}_{2}$ in Russia and Asia (MADRAS) during the period 2007-2012: instrumentation, elucidation of climatology, and comparisons with OMI satellite observations and global model simulations, Atmos Chem Phys, 14, 7909-7927, 10.5194/acp-14-7909-2014, 2014. 
Kanaya, Y. G., Cao, R. Q., Kato, S. G., Miyakawa, Y. K., Kajii, Y., Tanimoto, H., Yokouchi, Y., Mochida, M., Kawamura, K., and Akimoto, H.: Chemistry of $\mathrm{OH}$ and $\mathrm{HO}_{2}$ radicals observed at Rishiri Island, Japan, in September 2003: Missing daytime sink of $\mathrm{HO}_{2}$ and positive nighttime correlations with monoterpenes, J Geophys Res-Atmos, 112, 10.1029/2006jd007987, 2007c.

Kley, D., Crutzen, P. J., Smit, H. G. J., Vomel, H., Oltmans, S. J., Grassl, H., and Ramanathan, V.: Observations of near-zero ozone concentrations over the convective Pacific: Effects on air chemistry, Science, 274, 230-233, DOI 10.1126/science.274.5285.230, 1996.

Koenig, T. K., Baidar, S., Campuzano-Jost, P., Cuevas, C. A., Dix, B., Fernandez, R. P., Guo, H., Hall, S. R., Kinnison, D., Nault, B. A., Ullmann, K., Jimenez, J. L., Saiz-Lopez, A., and Volkamer, R.: Quantitative detection of iodine in the stratosphere, P Natl Acad Sci USA, 117, 1860-1866, 10.1073/pnas.1916828117, 2020.

Koenig, T. K., Volkamer, R., Baidar, S., Dix, B., Wang, S. Y., Anderson, D. C., Salawitch, R. J., Wales, P. A., Cuevas, C. A., Fernandez, R. P., Saiz-Lopez, A., Evans, M. J., Sherwen, T., Jacob, D. J., Schmidt, J., Kinnison, D., Lamarque, J. F., Apel, E. C., Bresch, J. C., Campos, T., Flocke, F. M., Hall, S. R., Honomichl, S. B., Hornbrook, R., Jensen, J. B., Lueb, R., Montzka, D. D., Pan, L. L., Reeves, J. M., Schauffler, S. M., Ullmann, K., Weinheimer, A. J., Atlas, E. L., Donets, V., Navarro, M. A., Riemer, D., Blake, N. J., Chen, D. X., Huey, L. G., Tanner, D. J., Hanisco, T. F., and Wolfe, G. M.: BrO and inferred $\mathrm{Br}-\mathrm{y}$ profiles over the western Pacific: relevance of inorganic bromine sources and a Br-y minimum in the aged tropical tropopause layer, Atmos Chem Phys, 17, 15245-15270, 10.5194/acp-17-15245-2017, 2017.

Lampel, J., Frieß, U., and Platt, U.: The impact of vibrational Raman scattering of air on DOAS measurements of atmospheric trace gases, Atmos Meas Tech, 8, 3767-3787, 10.5194/amt-8-3767-2015, 2015.

MacDonald, S. M., Martin, J. C. G., Chance, R., Warriner, S., Saiz-Lopez, A., Carpenter, L. J., and Plane, J. M. C.: A laboratory characterisation of inorganic iodine emissions from the sea surface: dependence on oceanic variables and parameterisation for global modelling, Atmos Chem Phys, 14, 5841-5852, 10.5194/acp-14-5841-2014, 2014.

Mahajan, A. S., Martin, J. C. G., Hay, T. D., Royer, S. J., Yvon-Lewis, S., Liu, Y., Hu, L., Prados-Roman, C., Ordonez, C., Plane, J. M. C., and Saiz-Lopez, A.: Latitudinal distribution of reactive iodine in the Eastern Pacific and its link to open ocean sources, Atmos Chem Phys, 12, 11609-11617, 10.5194/acp-12-11609-2012, 2012.

370 McFiggans, G., Plane, J. M. C., Allan, B. J., Carpenter, L. J., Coe, H., and O'Dowd, C.: A modeling study of iodine chemistry in the marine boundary layer, J Geophys Res-Atmos, 105, 14371-14385, Doi 10.1029/1999jd901187, 2000.

O'Dowd, C. D., Jimenez, J. L., Bahreini, R., Flagan, R. C., Seinfeld, J. H., Hameri, K., Pirjola, L., Kulmala, M., Jennings, S. G., and Hoffmann, T.: Marine aerosol formation from biogenic iodine emissions, Nature, 417, 632-636, DOI 10.1038/nature00775, 2002.

375 Platt, U. and Stutz, J.: Differential Optical Absorption Spectroscopy, Physics of Earth and Space Environments, SpringerVerlag Berlin Heidelberg, 10.1007/978-3-540-75776-4, 2008.

Pound, R. J., Sherwen, T., Helmig, D., Carpenter, L. J., and Evans, M. J.: Influences of oceanic ozone deposition on tropospheric photochemistry, Atmos Chem Phys, 20, 4227-4239, 10.5194/acp-20-4227-2020, 2020. 
Prados-Roman, C., Cuevas, C. A., Hay, T., Fernandez, R. P., Mahajan, A. S., Royer, S. J., Gali, M., Simo, R., Dachs, J., Großmann, K., Kinnison, D. E., Lamarque, J. F., and Saiz-Lopez, A.: Iodine oxide in the global marine boundary layer, Atmos Chem Phys, 15, 583-593, 10.5194/acp-15-583-2015, 2015a.

Prados-Roman, C., Cuevas, C. A., Fernandez, R. P., Kinnison, D. E., Lamarque, J. F., and Saiz-Lopez, A.: A negative feedback between anthropogenic ozone pollution and enhanced ocean emissions of iodine, Atmos Chem Phys, 15, 2215-2224, 10.5194/acp-15-2215-2015, $2015 b$.

Read, K. A., Mahajan, A. S., Carpenter, L. J., Evans, M. J., Faria, B. V. E., Heard, D. E., Hopkins, J. R., Lee, J. D., Moller, S. J., Lewis, A. C., Mendes, L., McQuaid, J. B., Oetjen, H., Saiz-Lopez, A., Pilling, M. J., and Plane, J. M. C.: Extensive halogen-mediated ozone destruction over the tropical Atlantic Ocean, Nature, 453, 1232-1235, 10.1038/nature07035, 2008.

Rex, M., Wohltmann, I., Ridder, T., Lehmann, R., Rosenlof, K., Wennberg, P., Weisenstein, D., Notholt, J., Kruger, K., Mohr, V., and Tegtmeier, S.: A tropical West Pacific $\mathrm{OH}$ minimum and implications for stratospheric composition, Atmos Chem Phys, 14, 4827-4841, 10.5194/acp-14-4827-2014, 2014.

Rothman, L. S., Gordon, I. E., Babikov, Y., Barbe, A., Benner, D. C., Bernath, P. F., Birk, M., Bizzocchi, L., Boudon, V., Brown, L. R., Campargue, A., Chance, K., Cohen, E. A., Coudert, L. H., Devi, V. M., Drouin, B. J., Fayt, A., Flaud, J. M., Gamache, R. R., Harrison, J. J., Hartmann, J. M., Hill, C., Hodges, J. T., Jacquemart, D., Jolly, A., Lamouroux, J., Le Roy, R. J., Li, G., Long, D. A., Lyulin, O. M., Mackie, C. J., Massie, S. T., Mikhailenko, S., Muller, H. S. P., Naumenko, O. V., Nikitin, A. V., Orphal, J., Perevalov, V., Perrin, A., Polovtseva, E. R., Richard, C., Smith, M. A. H., Starikova, E., Sung, K., Tashkun, S., Tennyson, J., Toon, G. C., Tyuterev, V. G., and Wagner, G.: The HITRAN2012 molecular spectroscopic database, J Quant Spectrosc Ra, 130, 4-50, 10.1016/j.jqsrt.2013.07.002, 2013.

Saiz-Lopez, A., Plane, J. M. C., Cuevas, C. A., Mahajan, A. S., Lamarque, J. F., and Kinnison, D. E.: Nighttime atmospheric chemistry of iodine, Atmos. Chem. Phys., 16, 15593-15604, 10.5194/acp-16-15593-2016, 2016.

Saiz-Lopez, A., Fernandez, R. P., Ordonez, C., Kinnison, D. E., Martin, J. C. G., Lamarque, J. F., and Tilmes, S.: Iodine chemistry in the troposphere and its effect on ozone, Atmos Chem Phys, 14, 13119-13143, 10.5194/acp-14-13119-2014, 2014.

Saiz-Lopez, A., Baidar, S., Cuevas, C. A., Koenig, T. K., Fernandez, R. P., Dix, B., Kinnison, D. E., Lamarque, J. F., Rodriguez-Lloveras, X., Campos, T. L., and Volkamer, R.: Injection of iodine to the stratosphere, Geophys Res Lett, 42, 6852-6859, 10.1002/2015g1064796, 2015.

Saiz-Lopez, A., Lamarque, J. F., Kinnison, D. E., Tilmes, S., Ordonez, C., Orlando, J. J., Conley, A. J., Plane, J. M. C., Mahajan, A. S., Santos, G. S., Atlas, E. L., Blake, D. R., Sander, S. P., Schauffler, S., Thompson, A. M., and Brasseur, G.: Estimating the climate significance of halogen-driven ozone loss in the tropical marine troposphere, Atmos Chem Phys, 12, 39393949, 10.5194/acp-12-3939-2012, 2012. 
Sakamoto, Y., Yabushita, A., Kawasaki, M., and Enami, S.: Direct emission of $\mathrm{I}_{2}$ molecule and IO radical from the heterogeneous reactions of gaseous ozone with aqueous potassium iodide solution, J Phys Chem A, 113, 7707-7713, 10.1021/jp903486u, 2009.

Sekiya, T., Kanaya, Y., Sudo, K., Taketani, F., Iwamoto, Y., Aita, M. N., Yamamoto, A., and Kawamoto, K.: Global Bromineand Iodine-Mediated Tropospheric Ozone Loss Estimated Using the CHASER Chemical Transport Model, Sola, 16, 220227, 10.2151/sola.2020-037, 2020.

Shaw, M. D. and Carpenter, L. J.: Modification of Ozone Deposition and I-2 Emissions at the Air-Aqueous Interface by Dissolved Organic Carbon of Marine Origin, Environ Sci Technol, 47, 10947-10954, 10.1021/es4011459, 2013.

Sherwen, T., Evans, M. J., Carpenter, L. J., Schmidt, J. A., and Mickley, L. J.: Halogen chemistry reduces tropospheric O-3 radiative forcing, Atmos Chem Phys, 17, 1557-1569, 10.5194/acp-17-1557-2017, 2017.

Sherwen, T., Schmidt, J. A., Evans, M. J., Carpenter, L. J., Großmann, K., Eastham, S. D., Jacob, D. J., Dix, B., Koenig, T. K., Sinreich, R., Ortega, I., Volkamer, R., Saiz-Lopez, A., Prados-Roman, C., Mahajan, A. S., and Ordonez, C.: Global impacts of tropospheric halogens $(\mathrm{Cl}, \mathrm{Br}, \mathrm{I})$ on oxidants and composition in GEOS-Chem, Atmos Chem Phys, 16, 1223912271, 10.5194/acp-16-12239-2016, 2016.

Simpson, W. R., Brown, S. S., Saiz-Lopez, A., Thornton, J. A., and von Glasow, R.: Tropospheric Halogen Chemistry: Sources, Cycling, and Impacts, Chem Rev, 115, 4035-4062, 10.1021/cr5006638, 2015.

Sinreich, R., Frieß, U., Wagner, T., and Platt, U.: Multi axis differential optical absorption spectroscopy (MAX-DOAS) of gas and aerosol distributions, Faraday Discuss, 130, 153-164; discussion 241-164, 519-124, 10.1039/b419274p, 2005.

Sipila, M., Sarnela, N., Jokinen, T., Henschel, H., Junninen, H., Kontkanen, J., Richters, S., Kangasluoma, J., Franchin, A., Perakyla, O., Rissanen, M. P., Ehn, M., Vehkamaki, H., Kurten, T., Berndt, T., Petaja, T., Worsnop, D., Ceburnis, D., Kerminen, V. M., Kulmala, M., and O'Dowd, C.: Molecular-scale evidence of aerosol particle formation via sequential addition of $\mathrm{HIO}_{3}$, Nature, 537, 532-534, 10.1038/nature19314, 2016.

Spurr, R. J. D.: VLIDORT: A linearized pseudo-spherical vector discrete ordinate radiative transfer code for forward model and retrieval studies in multilayer multiple scattering media, J Quant Spectrosc Ra, 102, 316-342, 10.1016/j.jqsrt.2006.05.005, 2006.

Stockwell, W. R., Kirchner, F., Kuhn, M., and Seefeld, S.: A new mechanism for regional atmospheric chemistry modeling, J Geophys Res-Atmos, 102, 25847-25879, Doi 10.1029/97jd00849, 1997.

Stutz, J., Hebestreit, K., Alicke, B., and Platt, U.: Chemistry of halogen oxides in the troposphere: Comparison of model calculations with recent field data, J Atmos Chem, 34, 65-85, Doi 10.1023/A:1006245802825, 1999.

440 Takashima, H., Kanaya, Y., and Taketani, F.: Downsizing of a ship-borne MAX-DOAS instrument, JAMSTEC Report of Research and Development, 23, 34-40, 10.5918/jamstecr.23.34, 2016.

Takashima, H., Irie, H., Kanaya, Y., and Akimoto, H.: Enhanced $\mathrm{NO}_{2}$ at Okinawa Island, Japan caused by rapid air-mass transport from China as observed by MAX-DOAS, Atmos Environ, 45, 2593-2597, 10.1016/j.atmosenv.2010.10.055, 2011. 
Takashima, H., Irie, H., Kanaya, Y., and Syamsudin, F.: $\mathrm{NO}_{2}$ observations over the western Pacific and Indian Ocean by MAXDOAS on Kaiyo, a Japanese research vessel, Atmos Meas Tech, 5, 2351-2360, 10.5194/amt-5-2351-2012, 2012.

Takashima, H., Shiotani, M., Fujiwara, M., Nishi, N., and Hasebe, F.: Ozonesonde observations at Christmas Island (2 degrees N, 157 degrees W) in the equatorial central Pacific, J Geophys Res-Atmos, 113, 10.1029/2007jd009374, 2008.

Takashima, H., Irie, H., Kanaya, Y., Shimizu, A., Aoki, K., and Akimoto, H.: Atmospheric aerosol variations at Okinawa Island in Japan observed by MAX-DOAS using a new cloud-screening method, J Geophys Res-Atmos, 114, 10.1029/2009jd011939, 2009.

Thalman, R. and Volkamer, R.: Temperature dependent absorption cross-sections of O-2-O-2 collision pairs between 340 and $630 \mathrm{~nm}$ and at atmospherically relevant pressure, Phys Chem Chem Phys, 15, 15371-15381, 10.1039/c3cp50968k, 2013.

Tinel, L., Adams, T. J., Hollis, L. D. J., Bridger, A. J. M., Chance, R. J., Ward, M. W., Ball, S. M., and Carpenter, L. J.: Influence of the Sea Surface Microlayer on Oceanic Iodine Emissions, Environ Sci Technol, 54, 13228-13237, 10.1021/acs.est.0c02736, 2020.

Tsunogai, S. and Henmi, T.: Iodine in the surface water of the ocean, Journal of the Oceanographical Society of Japan, 27, 6772, 10.1007/BF02109332, 1971.

Vandaele, A. C., Hermans, C., Simon, P. C., Carleer, M., Colin, R., Fally, S., Merienne, M. F., Jenouvrier, A., and Coquart, B.: Measurements of the $\mathrm{NO}_{2}$ absorption cross-section from $42000 \mathrm{~cm}(-1)$ to $10000 \mathrm{~cm}(-1)(238-1000 \mathrm{~nm})$ at $220 \mathrm{~K}$ and 294 K, J Quant Spectrosc Ra, 59, 171-184, Doi 10.1016/S0022-4073(97)00168-4, 1998.

Volkamer, R., Coburn, S., Dix, B., and Sinreich, R.: MAX-DOAS observations from ground, ship, and research aircraft: maximizing signal-to-noise to measure 'weak' absorbers, Proc.SPIE, 7462, 10.1117/12.826792, 2009.

Volkamer, R., Baidar, S., Campos, T. L., Coburn, S., DiGangi, J. P., Dix, B., Eloranta, E. W., Koenig, T. K., Morley, B., Ortega, I., Pierce, B. R., Reeves, M., Sinreich, R., Wang, S., Zondlo, M. A., and Romashkin, P. A.: Aircraft measurements of $\mathrm{BrO}$, IO, glyoxal, $\mathrm{NO}_{2}, \mathrm{H}_{2} \mathrm{O}, \mathrm{O}_{2}-\mathrm{O}_{2}$ and aerosol extinction profiles in the tropics: comparison with aircraft-/ship-based in situ and lidar measurements, Atmos Meas Tech, 8, 2121-2148, 10.5194/amt-8-2121-2015, 2015.

Wagner, T., Dix, B., von Friedeburg, C., Frieß, U., Sanghavi, S., Sinreich, R., and Platt, U.: MAX-DOAS O-4 measurements: A new technique to derive information on atmospheric aerosols - Principles and information content, J Geophys ResAtmos, 109, 10.1029/2004jd004904, 2004.

Watanabe, K., Matsuda, S., Cuevas, C. A., Saiz-Lopez, A., Yabushita, A., and Nakano, Y.: Experimental Determination of the Photooxidation of Aqueous I- as a Source of Atmospheric I-2, Acs Earth Space Chem, 3, 669-679, 10.1021/acsearthspacechem.9b00007, 2019.

Wittrock, F., Oetjen, H., Richter, A., Fietkau, S., Medeke, T., Rozanov, A., and Burrows, J. P.: MAX-DOAS measurements of atmospheric trace gases in Ny-Alesund - Radiative transfer studies and their application, Atmos Chem Phys, 4, 955966, DOI 10.5194/acp-4-955-2004, 2004. 